\title{
Nutritional status and physiological parameters of maize cultivated with sewage sludge
}

\section{Estado nutricional e parâmetros fisiológicos de milho cultivado com lodo de esgoto}

\author{
Rodrigo Santos Moreira' (D), Guilherme Henrique Expedito Lense' ${ }^{1}$ D, Leonardo Ferreira Fávero' (D), \\ Benedito Majela de Oliveira Junior ${ }^{1}$ (D), Ronaldo Luiz Mincato ${ }^{* *}$ (D)
}

${ }^{1}$ Universidade Federal de Alfenas/UNIFAL, Alfenas, MG, Brasil

${ }^{*}$ Corresponding author: ronaldo.mincato@unifal-mg.edu.br

Received in December 9, 2019 and approved in February 16, 2020

\begin{abstract}
The use of sewage sludge as a source of nutrients and organic matter for agricultural soils is a well-established practice. However, few reports highlight the effect of the nutrients and potentially toxic elements provided by organic wastes application on the plant physiological parameters, such as photosynthetic activity and stomatal conductivity. We performed a greenhouse experiment with maize exposed to a dystrophic red Latosol amended with mineral fertilizer and different rates of sewage sludge with the following objectives: i) assess the nutrients and metal uptake translocation and distribution in plants and ii) evaluate the relationship between plant physiological parameters and yield indicators under the study conditions. The application of sewage sludge increased the soil organic matter, $\mathrm{pH}$, and the amounts of available $\mathrm{Ca}, \mathrm{S}$, and $\mathrm{Mg}$, comparing to the mineral fertilizer treatment. The plants promote a higher translocation of macronutrients to the shoots in the sewage sludge treatments, which results in higher photosynthetic activity, stomatal conductivity, and maize yield parameters. Moreover, the trace elements, which can cause toxicity in small concentrations, were founded mainly in the roots, which indicates a plant defense mechanism.
\end{abstract}

Index terms: Biosolids; Zea mays; agricultural production; heavy metals.

\begin{abstract}
RESUMO
O uso de lodo de esgoto como fonte de nutrientes e matéria orgânica para solos agrícolas é uma prática bem estabelecida. Entretanto, poucos estudos destacam o efeito dos nutrientes e elementos potencialmente tóxicos fornecidos pela aplicação de resíduos orgânicos nos parâmetros fisiológicos da planta, como atividade fotossintética e condutividade estomática. Neste estudo, foi realizado um experimento em casa de vegetação com milho cultivado em um Latossolo Vermelho distrófico com adubação mineral e aplicação de diferentes concentrações de lodo de esgoto, com os seguintes objetivos: i) avaliar a translocação e distribuição de nutrientes e captação de metais em plantas de milho e ii) avaliar a relação entre os parâmetros fisiológicos e indicadores de produção das plantas nas condições do estudo. A aplicação do lodo de esgoto aumentou a matéria orgânica do solo, o pH e as quantidades de $\mathrm{Ca}$, S e Mg disponíveis, em comparação ao tratamento com fertilizantes minerais. As plantas promovem maior translocação de macronutrientes para a parte aérea nos tratamentos com aplicação de lodo de esgoto, o que resulta em maior atividade fotossintética, condutividade estomática e parâmetros de produção de milho. Além disso, os elementos traços, que podem causar toxicidade em pequenas concentrações, foram encontrados principalmente nas raízes, o que indica um mecanismo de defesa das plantas.
\end{abstract}

Termos para indexação: Biossólidos; Zea mays; produção agrícola; metais pesados.

\section{INTRODUCTION}

The use of municipal sewage sludge (SS) as a source of nutrients and organic matter for agricultural soils is a well-established practice in many parts of the world, such as England, Australia, the United States of America, and the European Union (Sharma et al., 2017). However, it is estimated that only $10 \%$ of the SS produced in Brazil is used for agricultural purposes, while the remainder is disposed of landfills (Borba et al., 2018).
Chemical fertilizers provide nutrients readily available to the plants. However, the availability of nutrients from SS depends on the residue decomposition rate and the interaction with the intrinsic characteristics of the soil-plant system (Antonkiewicz et al., 2019).

The SS characteristics change according to the origin of the solids and the type of processing used by the Wastewater Treatment Plant (Smith, 2009; Kim et al., 2017). Although several studies report positive results from 
SS application in several crops (Carbonell et al., 2011; Baioui et al., 2017; Abreu-Junior et al., 2019; Kępka et al., 2016), the heterogeneity of the residue raises doubts regarding their capacity to provide well-balanced nutrients to the plants.

Another factor that limits the use of SS in agriculture is the risk of soil and food contamination by heavy metals (Abreu-Junior et al., 2019; Moreira; Mincato; Santos, 2013). Some metals are essential nutrients required in small contents by the plants. However, in high concentrations, these elements can negatively affect plant physiological parameters, such as photosynthetic activity and stomatal conductivity, thereby reducing crop yields (Bączek-Kwinta, et al., 2019).

In general, SS research is still focused on its effects on plant growth and soil contamination by heavy metals. However, the physiological parameters of plants fertilized with this residue have not been completely clarified yet, and few reports highlight the effects of SS on the distribution of nutrients and potentially toxic elements in different parts of plants (Carbonell, et al., 2011). Thus, the study of the nutritional status and physiological parameters of maize cultivated with SS can help to choose SS rates according to the plant nutrients needs and avoid plant toxicity. In this work, a greenhouse experiment was conducted with maize exposed to a dystrophic red Latosol amended with mineral fertilizer and different rates of SS with the following objectives: i) assess the nutrients and metal uptake translocation and distribution in maize plants and ii) evaluate the relationship between plant physiological parameters and yield indicators under the study conditions.

\section{MATERIAL AND METHODS}

A greenhouse experiment with maize (Zea mays L.) was carried out in plastic pots of $25 \mathrm{dm}^{-3}$ capacity. We collected the soil in an area that has not been fertilized for the last 15 years, located at $21^{\circ} 25^{\circ}$ south latitude, and $45^{\circ} 57^{\prime}$ long west of Greenwich. The soil was classified as a dystrophic red Latosol, according to the Brazilian Classification System (Embrapa, 2013) and Ferralsol, according to the World Reference Base for Soil Resources
(WRB, 2015). The chemical characterization of soil used in the experiment was perform according to Raij (2001), and are present in Table 1.

The municipal SS was collected in a Wastewater Treatment Plant, located at Municipality of Paraguaçu, Minas Gerais State, Brazil. We collect six samples of the residue used in the experiment for chemical characterization. The $\mathrm{pH}$ was determined in a $\mathrm{CaCl}_{2}$ extract (1:5). The total soil organic carbon (TOC) and total nitrogen (TN) was determined by dry combustion, using an elemental analyzer $\mathrm{CN}$. The other elements were quantified by Inductively Coupled Plasma Optical Emission Spectrometry (ICP-OES) (Model Optma 7300 DV, Perkin Elmer). The results of SS chemical characterization are present in Table 2.

We validated the precision and accuracy of heavy metals analyses by simultaneous analyses of certified samples of sewage sludge (BCR-144R and BCR-145R) and soil treated with sewage sludge (CRM-143R) obtained in the Institute for Reference Materials and Measurements from the European Commission. We analyzed the samples under the same methodological procedures described and calculated the recovery factor to evaluate the analysis veracity (Brasil, 2011) (Table 3).

The experiment was performed in a completely randomized design with six treatments and four replicates. The treatments consisted of the following sewage sludge rates: 10 (SS1), 20 (SS2), 40 (SS3), 80 (SS4), and 160 (SS5) $\mathrm{Mg} \mathrm{ha}^{-1}$. The $10 \mathrm{Mg} \mathrm{ha}^{-1} \mathrm{SS}$ rates were defined based on CONAMA Resolution No. 375 (Conama, 2006) considered the nitrogen content of the residue. As a control, a mineral fertilizer treatment (MF) was added, according to Table 4.

Each pot was filled with $25 \mathrm{~kg}$ of soil previously mixed with the equivalent amount of SS or mineral fertilizer to reach the selected mentioned application rates. Then, the pots were incubated for 30 days. After the incubation time, four maize seeds were planted manually in the pots, which was previously watered for conditioning purposes. During the experiment, we kept the soil moisture close to $60 \%$ of the water-holding capacity. The harvest was performed 131 days after sowing when plants reached physiological maturity.

Table 1: Chemical characterization of soil used in the experiment.

\begin{tabular}{|c|c|c|c|c|c|c|c|c|c|c|c|c|c|c|c|}
\hline $\mathrm{pH}$ & V & $\mathrm{Al}$ & $\mathrm{H}+\mathrm{Al}$ & SB & СТC & K & $\mathrm{Ca}$ & $\mathrm{Mg}$ & $P$ & $\mathrm{Mn}$ & $\mathrm{Zn}$ & $\mathrm{Fe}$ & B & Total C & OM \\
\hline $\mathrm{H}_{2} \mathrm{O}$ & $\%$ & --- & - & ----- n & $\mathrm{nol}_{\mathrm{c}} \mathrm{dr}$ & 3 ---- & - & --- &..- & -.-. & $g \mathrm{dn}$ & -... & ---- & $\mathrm{g} \mathrm{dm}^{-3}$ & ----- \\
\hline 5.7 & 45 & 0 & 23 & 67.9 & 90.9 & 6.9 & 41 & 20 & 35 & 9.1 & 2.1 & 36 & 0.24 & 18 & 31 \\
\hline
\end{tabular}

V: base saturation; SB: sum of bases; OM: organic matter. 
Table 2: Chemical characterization of sewage sludge used in the experiment.

\begin{tabular}{ccc}
\hline Parameter & Concentration* & CONAMA** \\
\hline $\mathrm{pH}$ & 7.20 & -- \\
Total carbon (\%) & 23.6 & -- \\
$\mathrm{P}\left(\mathrm{g} \mathrm{kg}^{-1}\right)$ & 6.55 & -- \\
$\mathrm{K}\left(\mathrm{g} \mathrm{kg}^{-1}\right)$ & 0.41 & -- \\
$\mathrm{S}\left(\mathrm{g} \mathrm{kg}^{-1}\right)$ & 11.02 & -- \\
$\mathrm{Mg}\left(\mathrm{g} \mathrm{kg}^{-1}\right)$ & 4.32 & -- \\
$\mathrm{Ca}\left(\mathrm{g} \mathrm{kg}^{-1}\right)$ & 40.51 & -- \\
$\mathrm{B}\left(\mathrm{mg} \mathrm{kg}^{-1}\right)$ & 119.89 & -- \\
$\mathrm{Zn}\left(\mathrm{mg} \mathrm{kg}^{-1}\right)$ & 861.15 & 2800.00 \\
$\mathrm{Mn}\left(\mathrm{mg} \mathrm{kg}^{-1}\right)$ & 243.45 & -- \\
$\mathrm{Ni}\left(\mathrm{mg} \mathrm{kg}^{-1}\right)$ & 16.54 & 420.00 \\
$\mathrm{~Pb}\left(\mathrm{mg} \mathrm{kg}^{-1}\right)$ & 46.16 & 300.00 \\
$\mathrm{Mo}\left(\mathrm{mg} \mathrm{kg}^{-1}\right)$ & 1.50 & 50.00 \\
$\mathrm{Cd}\left(\mathrm{mg} \mathrm{kg}^{-1}\right)$ & 0.50 & 39.00 \\
$\mathrm{Cr}\left(\mathrm{mg} \mathrm{kg}^{-1}\right)$ & 83.46 & 1000.00 \\
$\mathrm{Cu}\left(\mathrm{mg} \mathrm{kg}^{-1}\right)$ & 134.67 & 1500.00 \\
\hline
\end{tabular}

* Average of 6 samples taken from the drying beds of the Wastewater Treatment Plant. ** Maximum concentration of heavy metals allowed according to the National Environment Council (CONAMA, 2006).

The leaf photosynthesis rate (A) and stomatal conductance (gs) were measured using a portable photosynthesis system (IRGA, LI-6400XT, Li-Color, Lincoln, NE, USA) and a chamber with an artificial light source (LI-6400-02B RedBlue) at 100 days of cultivation. After harvest, the plants were subdivided into leaves, stem, root, and grain for chemical analysis. We determine the quantities of $\mathrm{P}, \mathrm{K}, \mathrm{Ca}, \mathrm{Mg}, \mathrm{S}, \mathrm{Cr}, \mathrm{Cu}, \mathrm{B}, \mathrm{Ni}$, and $\mathrm{Zn}$, according to Malavolta; Vitti and Oliveira (1997). The biomass, harvest index, grain weight, cob weight, cob diameter, and cob length were analyzed to assess plant growth. Finally, soil samples of each pot were collected to analyze the chemical parameters according to Raij et al. (2001).

The data obtained were submitted to analysis of variance (ANOVA) followed by the Tukey test, considering a 5\% significance level. Principal Component Analysis (PCA) was used to verify the interrelationship of maize yield indicators. Statistical analyses were performed using $\mathrm{R}$ software ( $\mathrm{R}$ Development Core Team, 2011).

\section{RESULTS AND DISCUSSION}

\section{Uptake and translocation of nutrients and potential toxic elements in plants}

The soil chemical parameters analyzed are present in Table 5. The SS application increased the amounts of $\mathrm{Ca}, \mathrm{S}, \mathrm{Mg}$, as well as cation exchange capacity and soil base saturation (Table 4). The $\mathrm{pH}$ values in the SS treatments increased compared to the mineral fertilizer application and stayed within the suitable limit, according to Malavolta, Vitti and Oliveira (1997). The residue used in our study was treated with $\mathrm{CaO}$, which contributed to the $\mathrm{pH}$ increase, as well as base saturation and $\mathrm{Ca}$ contents. However, the amounts of $\mathrm{P}, \mathrm{B}$, and $\mathrm{Cu}$ were higher in the mineral fertilizer treatment.

The treatments with higher SS application rates presented higher averages compared to the mineral fertilizer treatment. In general, these results indicate that the addition of sewage sludge can be beneficial to soil and provides valuable plant nutrients, which is consistent with several other studies (Abreu-Junior et al., 2017; Melo et al., 2018; Carbonell et al., 2011).

Table 3: Certified samples of (BCR-144R and BCR-145R) sewage sludge and soil treated with sewage sludge (CRM143R).

\begin{tabular}{ccccccccrr}
\hline Metals & \multicolumn{3}{c}{ BCR 144-R } & \multicolumn{3}{c}{ BCR 145-R } & \multicolumn{3}{c}{ CRM 143-R } \\
\hline $\mathrm{mg} \mathrm{dm}^{-3}$ & Certified & Found & frec $\%$ & Certified & Found & frec $\%$ & Certified & Found & frec \% \\
$\mathrm{Cd}$ & $1.84 \pm 0.07$ & 1.8 & 97.8 & $3.50 \pm 0.15$ & 3.5 & 100 & $72 \pm 1.8$ & 70.1 & 97.4 \\
$\mathrm{Cr}$ & $90 \pm 6$ & 94 & 104.4 & $307 \pm 13$ & 294 & 95.8 & $426 \pm 12$ & 418 & 98.1 \\
$\mathrm{~Pb}$ & $96 \pm 1.6$ & 98 & 102.1 & $282 \pm 9$ & 285 & 101.1 & $174 \pm 5$ & 180 & 103.4 \\
$\mathrm{Mn}$ & $189 \pm 6$ & 193 & 102.1 & $156 \pm 4$ & 153 & 98.1 & $858 \pm 11$ & 859 & 100.1 \\
$\mathrm{Ni}$ & $44.9 \pm 1.5$ & 43 & 95.8 & $251 \pm 6$ & 255 & 101.6 & $1063 \pm 16$ & 1051 & 98.9 \\
\hline
\end{tabular}

$f_{\text {rec }}=$ Recovery fator. 
Table 4: Rates and source of nutrients applied in the mineral fertilizer treatment.

\begin{tabular}{ccc}
\hline Nutrients & Applied rate $\left(\mathrm{mg} \mathrm{kg}^{-1}\right)$ & Source \\
\hline $\mathrm{N}$ & 300 & $\mathrm{NH}_{4} \mathrm{H}_{2} \mathrm{PO}_{4}$ \\
$\mathrm{P}$ & 300 & $\mathrm{KH}_{2} \mathrm{PO}_{4}$ \\
$\mathrm{~K}$ & 200 & $\mathrm{KH}_{2} \mathrm{PO}_{4}$ \\
$\mathrm{~S}$ & 40 & $\mathrm{~K}_{2} \mathrm{SO}_{4}$ \\
$\mathrm{Mg}$ & 46 & $\mathrm{MgSO}_{4}{ }_{7} \mathrm{H}_{2} \mathrm{O}$ \\
$\mathrm{B}$ & 2.5 & $\mathrm{H}_{3} \mathrm{BO}_{3}$ \\
$\mathrm{Cu}$ & 7.5 & $\mathrm{CuSO}_{4} 5 \mathrm{H}_{2} \mathrm{O}$ \\
$\mathrm{Mo}$ & 0.5 & $\left(\mathrm{NH}_{4}\right)_{6} \mathrm{MO}_{7} \mathrm{O}_{24} 4 \mathrm{H}_{2} \mathrm{O}$ \\
$\mathrm{Zn}$ & 2.5 & $\mathrm{ZnSO}_{4} 7 \mathrm{H}_{2} \mathrm{O}$ \\
\hline
\end{tabular}

Source: Novais, Neves and Barros et al. (1991).

Treatments with SS and mineral fertilizer exhibited low levels of $P$ in leaves, which was below the suitable limits (2.5 - $\left.3.5 \mathrm{~g} \mathrm{~kg}^{-1}\right)$, according to the standard established by Malavolta, Vitti and Oliveira (1997). Although the high levels of $\mathrm{P}$ in the sewage sludge composition, its available to the plants depends on the mineralization kinetics of the organic matter, which releases the nutrient gradually (Øgaard; Brod, 2016). For this reason, the soil P content in the MF treatment was significantly higher than the SS treatments (Table 4). Despite this, the higher SS rates (SS4 and SS5) showed higher levels of $\mathrm{P}$ in the leaves, which can be explained by the increase of the soil organic matter found in these treatments (Figure 1). According to Souza et al. (2006), management practices that increase soil organic matter content improve the mineral $\mathrm{P}$ availability since the carboxylic and phenolic functional groups present in the organic matter are responsible for blocking the positively charged sites of $\mathrm{Fe}$ and $\mathrm{Al}$ oxides, reducing the $\mathrm{P}$ adsorption.

There was a low $\mathrm{K}$ translocation for the grains, which concentrated mainly in maize stalk and leaves (Figure 1). This result was expected once the $\mathrm{K}$ is associated with maize stalk structure and strength and is responsible for activating enzymes that act in the processes of photosynthesis and respiration (Hasanuzzaman et al., 2018). The SS presents low levels of $\mathrm{K}$ due to its high water solubility, which makes that much of the nutrient be leaching in the drying beds of the Wastewater Treatment Plant (Paglia et al., 2007). However, there was no significant difference to $\mathrm{K}$ content in leaves between SS4 and MF treatment.

Table 5: Effect of mineral fertilizer and different sewage sludge rates on the soil chemical parameters.

\begin{tabular}{|c|c|c|c|c|c|c|c|}
\hline \multirow[t]{2}{*}{ Soil parameters } & \multicolumn{7}{|c|}{ Treatments } \\
\hline & MF & SS1 & SS2 & SS3 & SS4 & SS5 & CV\% \\
\hline $\mathrm{pH}$ & $5.0 c$ & $5.8 b$ & $5.9 b$ & $5.9 b$ & $5.8 \mathrm{~b}$ & $6.3 a$ & 4.2 \\
\hline $\operatorname{SOM}\left(\mathrm{g} \mathrm{dm}^{-3}\right)$ & $30.0 b$ & $30.7 b$ & $34.1 a$ & $31.6 a b$ & $32.8 a$ & $33.6 a$ & 15.3 \\
\hline $\mathrm{P}\left(\mathrm{mg} \mathrm{dm}^{-3}\right)$ & $75.1 \mathrm{a}$ & $12.9 \mathrm{e}$ & 18.5ed & $21.2 \mathrm{dc}$ & $26.2 \mathrm{c}$ & $34.5 b$ & 19.3 \\
\hline $\mathrm{K}\left(\mathrm{mmol}_{\mathrm{c}} \mathrm{dm}^{-3}\right)$ & $6.0 \mathrm{a}$ & $4.8 a b$ & $5.2 a$ & $5.0 a$ & $4.2 a b$ & $2.9 \mathrm{~b}$ & 34.5 \\
\hline $\mathrm{Ca}\left(\mathrm{mmol}_{\mathrm{c}} \mathrm{dm}^{-3}\right)$ & $38.7 f$ & $43.9 e$ & $50.0 d$ & $56.0 c$ & $67.9 b$ & $95.4 a$ & 7.0 \\
\hline $\mathrm{S}(\mathrm{mg} \mathrm{dm}-3)$ & $2.0 a$ & $22.1 d$ & $25.4 d$ & $57.7 c$ & $129.5 b$ & $290.4 a$ & 17.8 \\
\hline $\mathrm{Mg}\left(\mathrm{mmol}_{\mathrm{c}} \mathrm{dm}^{-3}\right)$ & $15.1 d$ & $16.5 d$ & $18.4 \mathrm{c}$ & $18.0 \mathrm{c}$ & $21.3 b$ & $23.6 a$ & 6.4 \\
\hline $\mathrm{Zn}\left(\mathrm{mg} \mathrm{dm} \mathrm{m}^{-3}\right)$ & $3.9 b c$ & $2.4 d$ & $3.6 \mathrm{c}$ & $4.1 \mathrm{bc}$ & $4.7 b$ & $6.8 a$ & 18.9 \\
\hline $\mathrm{Ni}\left(\mathrm{mg} \mathrm{kg}^{-1}\right)$ & $0.21 a$ & $0.15 c$ & $0.18 b$ & $0.17 b$ & $0.20 a$ & $0.15 c$ & 7.3 \\
\hline $\mathrm{Pb}\left(\mathrm{mg} \mathrm{kg} \mathrm{k}^{-1}\right)$ & $0.80 a$ & $0.76 a$ & $0.74 a$ & $0.78 a$ & $0.69 a$ & $0.53 b$ & 14.8 \\
\hline $\mathrm{B}\left(\mathrm{mg} \mathrm{kg}^{-1}\right)$ & $0.54 a$ & $0.37 \mathrm{~cd}$ & $0.32 \mathrm{de}$ & $0.43 b c$ & $0.49 a b$ & $0.26 \mathrm{e}$ & 18.9 \\
\hline $\mathrm{Cr}$ & $0.02 a$ & $0.02 a$ & $0.02 a$ & $0.02 a$ & $0.02 a$ & $0.005 b$ & 31.6 \\
\hline $\mathrm{Cu}$ & $2.30 a$ & $1.18 c$ & $1.44 b$ & $1.38 b$ & $1.40 \mathrm{~b}$ & $1.20 c$ & 6.8 \\
\hline $\mathrm{CEC}\left(\mathrm{mmol}_{\mathrm{c}} \mathrm{dm}^{-3}\right)$ & $93.1 d$ & $86.0 \mathrm{e}$ & $96.5 \mathrm{~cd}$ & $102.0 c$ & $116.6 b$ & $137.5 a$ & 5.0 \\
\hline Base saturation & $64.4 d$ & $75.8 \mathrm{c}$ & $76.9 b c$ & $78.4 \mathrm{bc}$ & $80.3 b$ & $88.4 a$ & 3.8 \\
\hline
\end{tabular}

* Means followed by the same letters do not differ statistically according to the t-test at $\mathrm{P} \leq 0.05$. CV\% = coefficient of variation. $\mathrm{SOM}=$ soil organic matter; $\mathrm{CEC}=$ cation exchange capacity; MF = Mineral fertilizer; SS1 = $10 \mathrm{Mg} \mathrm{ha}^{-1} ; \mathrm{SS}_{2}=20 \mathrm{Mg}^{\mathrm{a}}{ }^{-1} ; \mathrm{SS} 3=40$ $\mathrm{Mg} \mathrm{ha}^{-1} ; \mathrm{SS} 4=80 \mathrm{Mg} \mathrm{ha}^{-1} ;$ SS5 $=160 \mathrm{Mg} \mathrm{ha}^{-1}$. 
In general, treatments with higher SS rates showed higher levels of $\mathrm{Ca}$ in plant tissue, which was concentrated mainly in leaves and roots, presenting low translocation to the grains (Figure 1). Similar to $\mathrm{Ca}$, the increase of SS rates incremented the levels of $\mathrm{Mg}$ and $\mathrm{S}$ tissues (Figure 1), which indicates the potential of residue to provide these nutrients to the plants.

Regarding trace elements, higher concentrations of $\mathrm{Cr}, \mathrm{B}, \mathrm{Cu}, \mathrm{Ni}$, and $\mathrm{Mn}$ were found mainly in the roots (Figure 2), which can be a defense mechanism of the plants, as high concentrations of these elements can cause toxicity and a decline in the photosynthesis rates (Marco et al., 2016). The Cd contents in the plant tissues were below the ICP-OES limit detection.

These results are in agreement with Carbonell et al. (2011) and Bay et al. (2017), who observed that the root system acts as a barrier to the uptake of heavy metals generating low concentrations in the shoots.

Although the increase of the SS rates promoted an increment of $\mathrm{Zn}$ in the soil (Table 5), the SS2 treatment presented higher $\mathrm{Zn}$ content in the leaves (Figure 2). This result can be explained by the increase in soil organic matter content, which can complex this element, reducing its availability to plants (Moreira; Mincato; Santos, 2013).

We found $67.2 \mathrm{mg} \mathrm{kg}^{-1} \mathrm{Zn}$ in the SS2 treatment, which is higher than the suitable range of $15.0-50.0 \mathrm{mg}$ $\mathrm{kg}^{-1}$ (Malavolta; Vitti; Oliveira, 1997), but smaller than 500 $\mathrm{mg} \mathrm{kg}^{-1}$, considered the limit to the element reaches the toxic level (Kabata-Pendias; Pendias, 2001). From the point of view of grain quality for human nutrition, $\mathrm{Zn}$ contents in maize grains are of great interest. $\mathrm{Zn}$ deficiency in humans
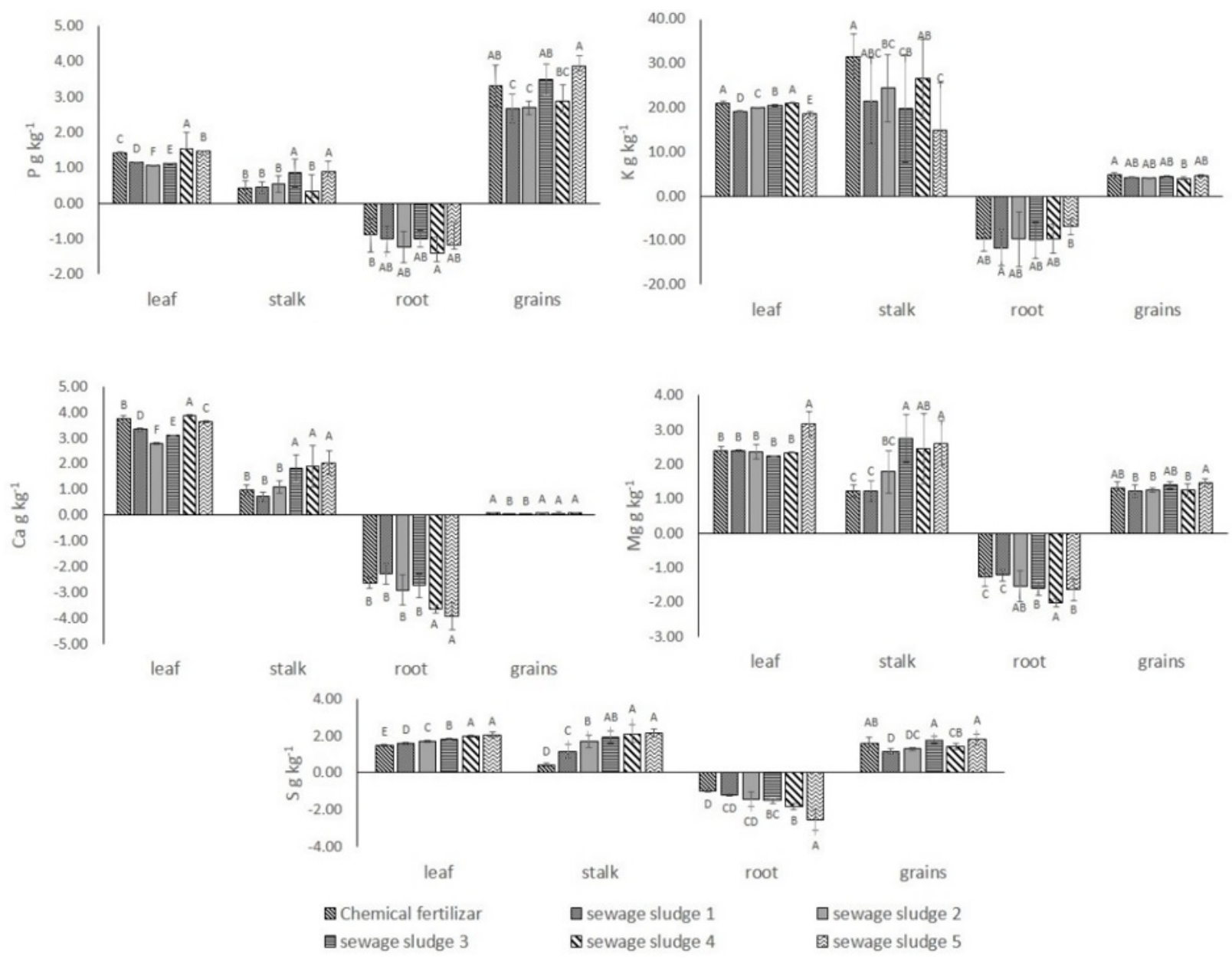

grains
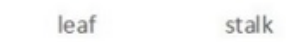

root

grains

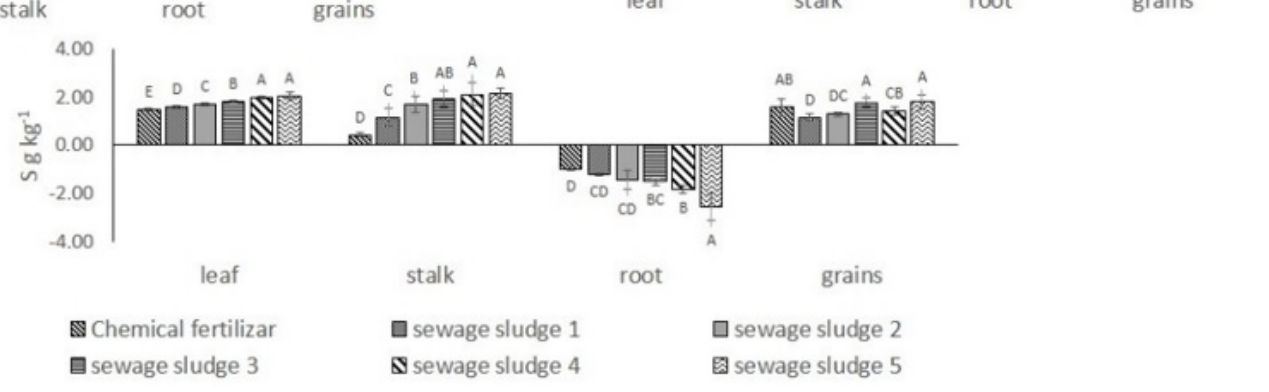

Figure 1: Effect of mineral fertilizer and sewage sludge rates on the distribution of macronutrients in different parts of maize plants. 


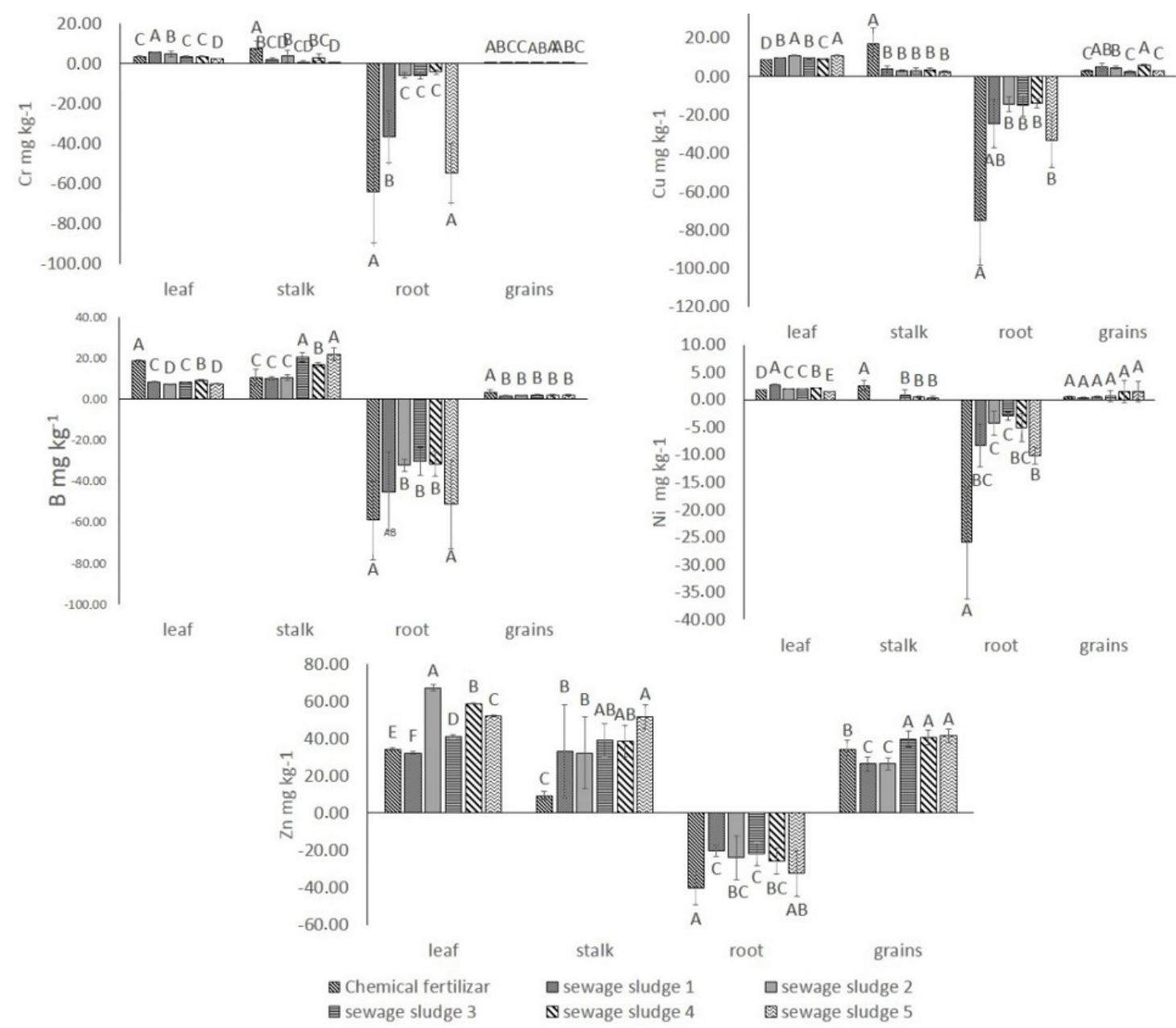

Figure 2: Effect of mineral fertilizer and sewage sludge rates on the distribution of trace elements in different parts of maize plants.

is a malnutrition problem worldwide (Roohani et al., 2013) and, it is more widespread in areas of high cereal and low animal food consumption (Mackowiak et al., 2011). Thus, SS application to soil seems to be a practical approach to improving grain $\mathrm{Zn}$ concentrations in staple foods, like maize.

\section{Physiological parameters and plant growth}

Sewage sludge application promoted a significant increase of maize photosynthetic activity and stomatal conductivity compared to mineral fertilizer (Table 6). According to Baioui et al. (2017), there is a strong relationship between photosynthetic activity and adequate nutrient supply provided by organic wastes.

Several studies showed that the photosynthetic physiology activities of the plant were inhibited markedly by heavy metals stress. However, this not seemed to be our case because the heavy metals supplied by the application of SS did not negatively affect the photosynthetic activity of plants. These results probably happened due to the low translocation of these elements to the shoots, since most metals accumulated in the roots.

The improvement of physiological parameters of plants promoted a higher biomass production, once the photosynthesis is the way of plants accumulating organic matter and produce biomass. The SS5 treatment provided an increase of $21 \%$ in the biomass production compared to the MF treatment. These results are in agreement with Bai et al. (2017) that found a higher biomass production of maize cultivated with SS. The treatments with higher SS rates also provided an increase in cob length, weight, and diameter. However, the harvest index presented a slight variation among treatments. 
The results of the principal component analysis for the maize yield indicators analyzed in this study are present in Figure 3. The interaction between the two main components demonstrated that there is a close relationship

Table 6: Yield indicators of maize cultivated with different sewage sludge rates and mineral fertilizers.

\begin{tabular}{|c|c|c|c|c|c|c|c|c|}
\hline Treat. & Wg & A & gs & Biomass & $\mathrm{Cob}_{w}$ & $\mathrm{Cob}_{1}$ & $\mathrm{Cob}_{d}$ & hi \\
\hline & $\mathrm{g} \mathrm{kg}^{-1}$ & $\mu \mathrm{mol} \mathrm{m} \mathrm{m}^{-2} \mathrm{~s}^{-1}$ & $\mathrm{~mol} \mathrm{~m}^{2} \mathrm{~s}^{-1}$ & \multicolumn{2}{|c|}{------------g---------- } & \multicolumn{2}{|c|}{---------cm--------- } & --- \\
\hline MF & $21.0 b$ & $42.8 \mathrm{~b}$ & $0.2 b$ & $162.7 \mathrm{cb}$ & $115.8 b$ & 140.7ab & 43.0ab & $38.1 \mathrm{a}$ \\
\hline SS1 & $20.1 c$ & $69.5 a$ & $0.4 a b$ & $136.0 d$ & $85.9 c$ & $122.0 \mathrm{c}$ & $40.6 b$ & 34.7ab \\
\hline SS2 & $20.3 c$ & $74.6 a$ & $0.6 a$ & $158.5 b c$ & $95.5 c$ & 133.0abc & $41.0 \mathrm{~b}$ & $33.4 b$ \\
\hline SS3 & $20.9 b$ & $76.8 \mathrm{a}$ & $0.6 a$ & $142.7 \mathrm{~cd}$ & $93.1 \mathrm{c}$ & $129.2 b c$ & $41.3 b$ & $35.4 a b$ \\
\hline SS4 & $22.8 a$ & $83.1 \mathrm{a}$ & $0.6 a$ & 179.6ab & 119.1ab & $145.2 a$ & 42.8ab & $36.2 \mathrm{ab}$ \\
\hline SS5 & $23.1 \mathrm{a}$ & $75.2 \mathrm{a}$ & $0.5 a$ & 197.0a & 134.0a & $144.5 a$ & $46.0 a$ & $36.4 a b$ \\
\hline CV\% & 1.5 & 16.6 & 26.8 & 11.2 & 12.1 & 7.6 & 7.0 & 8.5 \\
\hline
\end{tabular}

Means followed by the same later doo not differ according to t-test at $\mathrm{p}<0.05$. Treat. = treatment; MF = mineral fertilizer; SS1 = $10 \mathrm{Mg}$ $\mathrm{ha}^{-1} ; \mathrm{SS} 2=20 \mathrm{Mg} \mathrm{ha}^{-1} ; \mathrm{SS3}=40 \mathrm{Mg} \mathrm{ha}^{-1} ; \mathrm{SS} 4=80 \mathrm{Mg} \mathrm{ha}^{-1} ; \mathrm{SS} 5=160 \mathrm{Mg} \mathrm{ha}^{-1}$. Wg = weight of 1000 grains; $\mathrm{A}=$ photosynthetic activity; gs = stomatal conductivity; $\mathrm{Cob}_{\mathrm{w}}=\mathrm{cob}$ weight; $\mathrm{Cob}_{1}=\mathrm{cob}$ length; $\mathrm{Cob}_{\mathrm{d}}=\mathrm{cob}$ diameter; $\mathrm{hi}=$ harvest index; $\mathrm{CV} \%=$ coefficient of variation .

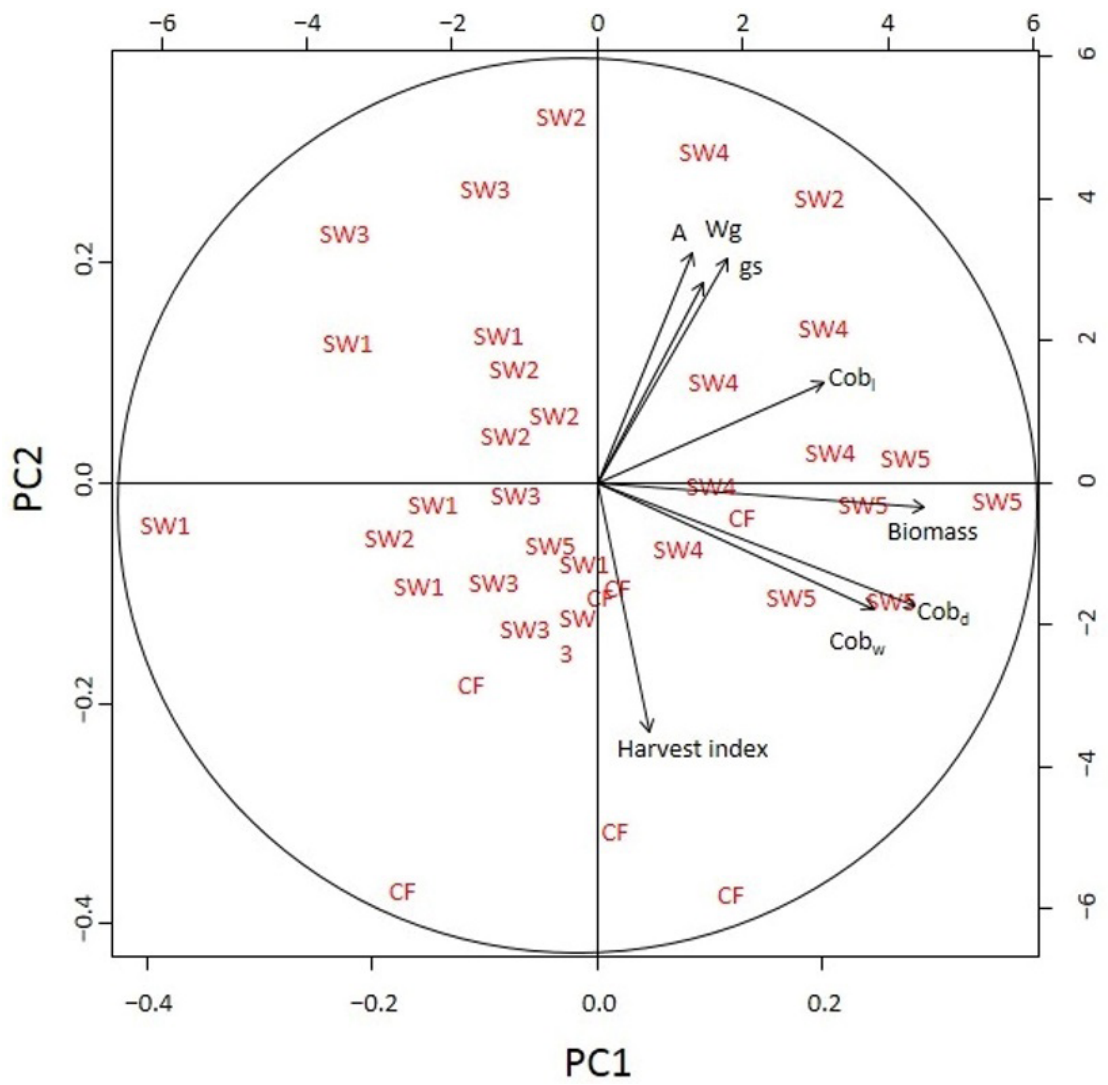

Figure 3: Principal components analyses of maize yield indicators cultivated with chemical fertilizer and different sewage sludge rates. $\mathrm{MF}=$ mineral fertilizer; SS1 $=10 \mathrm{Mg}^{-1} ; \mathrm{SS} 2=20 \mathrm{Mg} \mathrm{ha}^{-1} ; \mathrm{SS} 3=40 \mathrm{Mg} \mathrm{ha}^{-1} ; \mathrm{SS} 4=80 \mathrm{Mg} \mathrm{ha}^{-1}$; SS5 = $160 \mathrm{Mg} \mathrm{ha}^{-1}$. Wg = weight of 1000 grains; $\mathrm{A}=$ photosynthetic activity; gs = stomatal conductivity; $\operatorname{Cob}_{\mathrm{w}}=\mathrm{cob}$ weight; $\mathrm{Cob}_{1}=$ cob length; $\mathrm{Cob}_{\mathrm{d}}=\mathrm{cob}$ diameter. 
between the yield maize components. For analyzing the first principal component in the axis 1 , there is a clear separation between treatments. On the right are the treatments with higher SS rates (SS4 and SS5), which showed a good correlation with yield indicators. On the left are the treatments with the lowest SS rates that, in general, presented the lowest yield indicators values. The mineral fertilizer treatment was distributed between the two groups, demonstrating an intermediary position considering the SS rates.

The positive effect of the SS application on the photosynthetic activity and stomatal conductivity with consequent increases in biomass and other maize yield indicators is due to the higher soil nutrient availability and the additional benefits generated by the soil-plant system, such as higher water retention and improved soil biological activity, which are benefits promoted by the SS application widely documented in the literature (Glab, et al. 2020; Vieira; Pazianotto, 2016).

\section{CONCLUSIONS}

The application of sewage sludge improved soil properties compared to mineral fertilizer, promoting an increase in organic matter, nutrients, and $\mathrm{pH}$, with better results found in the highest applied rates. The plants promote a higher translocation of macronutrients to the shoots in the sewage sludge treatments, which results in higher photosynthetic activity, stomatal conductivity, and maize yield parameters. Moreover, the trace elements, which can cause toxicity in small concentrations, were founded mainly in the roots, which indicates a plant defense mechanism.

\section{ACKNOWLEDGEMENTS}

This study was financed in part by the Coordenação de Aperfeiçoamento de Pessoal de Nível Superior - Brasil (CAPES) - Finance Code 001. The authors thank the Fundação de Amparo à Pesquisa do Estado de Minas Gerais (FAPEMIG) for the scholarship offered to the second author and the Conselho Nacional de Desenvolvimento Científico e Tecnológico (CNPQ) for the scholarship offered to the fourth author.

\section{REFERENCES}

ABREU-JUNIOR, C. H. et al. Fertilization using sewage sludge in unfertile tropical soils increased wood production in Eucalyptus plantations. Journal of Environmental Management, 203(1):51-58, 2017.
ABREU-JUNIOR, C. H. et al. Effects of sewage sludge application on unfertile tropical soils evaluated by multiple approaches: A field experiment in a commercial Eucalyptus plantation. Science of the Total Environment, 655(1):1457-1467, 2019.

ANTONKIEWICZ, J. et al. Effect of municipal sewage sludge on soil chemical properties and chemical composition of spring wheat. Ecological Chemistry and Engineering, 26(3):583-595, 2019.

BĄCZEK-KWINTA, R. et al. Photosynthetic response of cabbage in cadmium-spiked soil. Photosynthetica, 57(3):731-739, 2019.

BAI, Y. et al. Sewage sludge as an initial fertility driver for rapid improvement of mudflat salt-soils. Science of the Total Environment, 578(1):47-55, 2017.

BAIOUI, R. et al. Agricultural valorization of domestic sewage sludge: Impact on growth, photosynthesis, nutrition and toxic metal accumulation in Medicago sativa. Agrochimica, 61(1):56-74, 2017.

BORBA, R. P. et al. Ion leaching and soil solution acidification in a vadose zone under soil treated with sewage sludge for agriculture. Chemosphere, 192(1):81-89, 2018.

BRASIL. Ministério da Agricultura, Pecuária e Abastecimento. Guia de validação e controle de qualidade analítica: fármacos em produtos para alimentação e medicamentos veterinários. Ministério da Agricultura, Pecuária e Abastecimento. Secretaria de Defesa Agropecuária. Brasília: MAPA, 2011. 72p.

CARBONELL G. et al. Effects of municipal solid waste compost and mineral fertilizer amendments on soil properties and heavy metals distribution in maize plants (Zea mays L.). Chemosphere, 85(10):1614-1623, 2011.

CONSELHO NACIONAL DO MEIO AMBIENTE CONAMA. Resoluções $n^{\circ} \mathbf{3 7 5}$ e $\mathbf{n}^{\circ} \mathbf{3 8 0}$, de $\mathbf{2 9}$ de agosto de 2006. Available in: <http://www2.mma.gov.br/port/ conama/res/res06/res37506.pdf>. Access in:JAN. 24, 2020.

EMBRAPA, EMPRESA BRASILEIRA DE PESQUISA AGROPECUÁRIA. Sistema brasileiro de classificação de solos. $3^{\circ}$ edição. Brasília, DF: Embrapa Solos, 2013. 353p.

GLAB, T. et al. Fertilization effects of compost produced from maize, sewage sludge and biochar on soil water retention and chemical properties. Soil and Tillage Research, 197(1): 104493, 2020.

HASANUZZAMAN, M. et al. Plant nutrients and abiotic stress tolerance. Singapore: Springer, 2018. 590p. 
KABATA-PENDIAS, A.; PENDIAS, $\mathrm{H}$. Trace elements in soils and plants. 3.ed. London: Boca Raton, 2001. 413p

KĘPKA, W. et al. The effect of municipal sewage sludge on the chemical composition of spring barley. Soil Science Annual, 67(3):124-130, 2016.

$\mathrm{KIM}$, M. et al. Review of contamination of sewage sludge andamended soils by polybrominated diphenyl ethers based on meta-analysis. Environmental Pollution, 220(1):753-765, 2017.

MACKOWIAK, C. L. et al. Yield and mineral concentration of Southeastern United States oat cultivars used for forage. Journal of Plant Nutrition, 34(12):1828-1842, 2011.

MALAVOLTA, E.; VITTI, G. C.; OLIVEIRA, S. A. Avaliação do estado nutricional das plantas: Princípios e aplicações. 2. ed. Piracicaba: Potafos, 1997. 319p.

MARCO, R. et al. Copper phytoaccumulation and tolerance by seedlings of native Brazilian trees. Environmental Engineering Science, 33(3):176-184, 2016.

MELO, W. et al. Ten years of application of sewage sludge on tropical soil. A balance sheet on agricultural crops and environmental quality. Science of The Total Environment, 643(1): 1493-1501, 2018.

MOREIRA, R. S.; MINCATO, R. L.; SANTOS, B. R. Heavy metals availability and soil fertility after land application of sewage sludge on dystroferric Red Latosol. Ciência e Agrotecnologia, 37(6):512-520, 2013.

NOVAIS, R. F.; NEVES, J. C. L.; BARROS, N. F. Ensaio em ambiente controlado. In: OLIVEIRA, A. J. et al. Métodos de pesquisa em fertilidade do solo. Brasília: Embrapa SEA, v.1, p.189253, 1991.

ØGAARD, A. F.; BROD, E. Efficient phosphorus cycling in food production: Predicting the phosphorus fertilization effect of sludge from chemical wastewater treatment. Journal of Agricultural and Food Chemistry, 64(24):4821-4829, 2016.

PAGLIA, E. C. et al. Doses de potássio na lixiviação do solo com lodo de esgoto. Revista Brasileira de Engenharia Agrícola e Ambiental, 11(1):94-100, 2007.

R DEVELOPMENT CORE TEAM. R: A language and environment for statistical computing. R Foundation for Statistical Computing, Vienna, Austria, 2011. Available in: <http:// www.r-project.org>. Access in: 28 Feb. 2019.

RAIJ, B. V. et al. Análises químicas para avaliação da fertilidade de solos tropicais. Campinas: Instituto Agronômico de Campinas, 2001. 285p.

ROOHANI, N. et al. Zinc and its importance for human health: An integrative review. Journal of Research in Medical Sciences, 18(2):144-157, 2013.

SHARMA, B. et al. Agricultural utilization of biosolids: A review on potential effects on soil and plant grown. Waste Management, 64(1):117-132, 2017.

SMITH, S. R. A critical review of the bioavailability and impacts of heavy metals inmunicipal solid waste composts compared to sewage sludge. Environment International, 35(1):142156, 2009.

SOUZA, R. F. et al. Calagem e adubação orgânica: Influência na adsorção de fósforo em solos. Revista Brasileira de Ciência do Solo, 30(6):975-983, 2006.

VIEIRA, R. F.; PAZIANOTTO, R. A. A. Microbial activities in soil cultivated with corn and amended with sewage sludge. SpringerPlus, 5(1844):1-16, 2016.

WRB, WORLD REFERENCE BASE FOR SOIL RESOURCES, Update. International soil classification system for naming soils and creating legends for soil maps. Food and Agriculture Organization of the United Nations, Rome, 2015. 192p. 